\section{Research Square}

\title{
High Rate of Bleeding and Arterial Thrombosis in COVID-19: Saudi Multicenter Study
}

\author{
Abdulrahman Al Raizah ( $\nabla$ alzairaab@ngha.med.sa ) \\ National Guard Health Affairs https://orcid.org/0000-0002-4215-1398 \\ Ahmed AlAskar \\ king abdullah international medical research center \\ Naila Shaheen \\ KAIMRC: King Abdullah International Medical Research Center \\ Khalid Aldosari \\ KAIMRC: King Abdullah International Medical Research Center \\ Mohamed Alnahdi \\ KAIMRC: King Abdullah International Medical Research Center \\ Musumadi Luhanga \\ KAIMRC: King Abdullah International Medical Research Center \\ Turki Alshuaibi \\ King Fahad Hospital Jeddah
}

\section{Wail Bajhmoum}

King Fahad Hospital

Khaled Alharbi

King Fahad Hospital Jeddah

Ghaida Alsahari

King Fahad Hospital Jeddah

Hadeel Algahtani

King Fahad Hospital Jeddah

\section{Eunice Alrayes}

Prince Mohammed Bin Abdul Aziz Hospital

Abdulrahim Basendwah

king fahad armed force hospital

Alia Abotaleb

king fahad armed force hospital

Mosaad Almegren

imam mohamed bin saud university

\section{Research}


Keywords: SARS-CoV2, COVID-19, coronavirus, bleeding, thrombosis, venous thromboembolism, arterial thrombosis, Saudi.

Posted Date: October 26th, 2020

DOI: https://doi.org/10.21203/rs.3.rs-94344/v1

License: (c) (i) This work is licensed under a Creative Commons Attribution 4.0 International License. Read Full License 


\section{Abstract}

Background: Coronavirus disease 2019 (COVID-19) is a global pandemic with a substantial impact on mortality, the health system and the economy ${ }^{8,9}$. Several observational studies reported the rate of venous and arterial thrombotic events in patients infected with COVID-19, with conflicting results. The aim of this multicentre study was to estimate the rate of thrombotic and bleeding events in hospitalized patients diagnosed with COVID-19 in Saudi Arabia.

Method: multicenter study of 636 hospitalized patients with COVID-19.

Result: Twelve patients were diagnosed with VTE 1.89\% (95\% Cl, 1.18-3). The rate in the non-ICU group was $0.19 \%(95 \% \mathrm{Cl}, 0.04-0.84)$ compared to $10.38 \%(95 \% \mathrm{Cl}, 6.45-16.27)$ in the ICU group. Fourteen patients were diagnosed with an arterial event with an overall rate of $2.20 \%(95 \% \mathrm{Cl}, 1.43-3.38)$. The rate in the non-ICU group was $0.94 \%(95 \% \mathrm{Cl}, 0.46-0.1 .93)$ and $8.49 \%(95 \% \mathrm{Cl}, 5.01-14.04)$ in the ICU group. The overall composite events rate was $2.99 \%(95 \% \mathrm{Cl}, 2.06-4.31)$. The composite events rate in the nonICU group was $0.94 \%(95 \% \mathrm{Cl}, 0.46-0.1 .93)$ and $13.21 \%(95 \% \mathrm{Cl}, 8.7-19.54)$ in the ICU group. Eleven patients developed bleeding with an overall rate of $1.73 \%(95 \% \mathrm{Cl}, 1.06-2.81)$. The bleeding rate in the non-ICU group was $0.19 \%(95 \% \mathrm{Cl}, 0.04-0.84)$, and $9.43 \%(95 \% \mathrm{Cl}, 5.72-15.16)$ in the ICU group. Of the selected risk factors, the only risk factor that predicted VTE and the composite outcome, was the baseline D-dimer. (OR 1.31, 95\% Cl, 1.084-1.573, p=0.005) and composite events (OR 1.32, 95\% Cl, 1.126-1.555, $p=0.0007)$.

Conclusion: Of 636 adults with COVID-19, the rate of VTE was similar to the rate of hospitalized patients with a similar degree of critical illness. In contrast to the risk of VTE, we found a high rate of arterial and bleeding complications in patients admitted to ICU. An elevated D-dimer at baseline could predict a thrombotic complication in the COVID-19 patients, which may assist in the identification of these patients. Given the high rate of bleeding, the current study suggests that the intensification of anticoagulation in COVID-19 patients beyond the standard of care, should be pursued with caution and is best evaluated in a randomised controlled study.

\section{Introduction}

Venous thromboembolism (VTE) is a leading cause of preventable hospital mortality ${ }^{1}$. Approximately $50 \%$ of VTE events occurring outside of a hospital, are due to a recent hospitalization ${ }^{2}$. There are several risk factors for hospital acquired VTE, including acute illness, surgery, obesity, trauma, limited mobility, the presence of a central venous catheter, previous history of thrombosis and old age $\mathrm{e}^{3}$. The increased risk for VTE may persist for months after discharge ${ }^{4}$. It is estimated that $70 \%$ of hospital acquired VTE can be prevented through pharmacological or mechanical methods, however, less than $50 \%$ of the patients receive such preventive measures ${ }^{5-7}$. Coronavirus disease 2019 (COVID-19) is a global pandemic with a substantial impact on mortality, the health system and the economy ${ }^{8,9}$. Several observational studies reported the rate of venous and arterial thrombotic events in patients infected with COVID-19, with 
conflicting results. Early studies showed an increased risk of thrombosis in COVID-19 patients, especially in critically ill patients with a crude cumulative composite outcome of venous and arterial events of

$57 \%{ }^{10-14}$. However, some studies reported a low rate of thrombotic events ${ }^{15-17}$. The aim of this multicentre study was to estimate the rate of thrombotic and bleeding events in hospitalized patients diagnosed with COVID-19 in Saudi Arabia.

\section{Method}

\section{Patients and Data Collection}

We included consecutive patients, aged $\geq 18$ years, admitted from the $20^{\text {th }}$ March to the $31^{\text {st }}$ May 2020 with confirmed COVID-19 in four hospitals. A confirmed COVID-19 case was defined as a positive reversetranscriptase polymerase chain reaction (RT-PCR) test by nasal or oropharyngeal swab. Patients were excluded if they were transferred from hospital to hospital or admitted for less than 24 hours. The sample was categorized as intensive care unit (ICU) patients or as ward patients. ICU patients could be admitted to the ICU at any time during hospital admission. Data were collected retrospectively through a manual chart review from the electronic and paper medical records, from the first day of admission until discharge or death or the end of data collection period, the $15^{\text {th }}$ of July 2020 . The data were collected using a standardized form and included baseline characteristics, comorbidities, ICU admission, hospital length of stay, hospital discharge or death, bleeding and thrombotic events, dose and type of anticoagulation used, mechanical prophylaxis use and coagulation parameters. This study was approved by the Institutional Review Board of all four hospitals. Due to the retrospective nature of this study, written informed consent was waived.

\section{Outcome}

The primary outcome was the rate of VTE. The secondary outcomes were the rate of arterial events, rate of composite events (venous and arterial) and the rate of bleeding. VTE included all symptomatic or incidentally diagnosed pulmonary embolism (PE), deep vein thrombosis (DVT) and thrombosis in unusual sites (cerebral veins, mesenteric, portal, splenic, hepatic, and renal). All VTE were confirmed radiographically by appropriate imaging. We also included PE that was not confirmed radiologically but highly suspected by the treating physician, based on a combination of clinical signs, symptoms, cardiac enzymes, electrocardiogram, and or echocardiogram monitoring. Screening for VTE in asymptomatic patients was not performed. If DVT and PE occurred in the same patient, it was considered as one event. Arterial events included cerebrovascular accident (CVA), mesenteric ischemia, and limb ischemia, confirmed by an appropriate imaging modality. Myocardial infarction (MI) was diagnosed based on the suspicion of the attending physician using clinical criteria as well as biomarker elevation or electrocardiographic changes. The composite events were defined as any VTE or arterial events. Bleeding events were classified as major and non-major, based on the definition proposed by the International Society of Thrombosis and Haemostasis (ISTH). Major bleeding was defined as fatal bleeding, or symptomatic bleeding in a critical organ, like intracranial, intraocular intraspinal, intra-articular, 
retroperitoneal, or pericardial, or intramuscular with compartment syndrome, or bleeding leading to a drop in haemoglobin level of $20 \mathrm{gL}$ or more, or leading to transfusion of 2 or more red blood cells. All other bleeding episodes were considered non-major bleeding ${ }^{18}$. The baseline D-dimer was defined as the first D-dimer after admission and the normal level for the D-dimer as less than $0.5 \mathrm{mcg} / \mathrm{ml}$.

\section{Statistical analysis}

Gender, nationality, history of cancer, history of thrombophilia, history of DVT, mechanical prophylaxis, enoxaparin dose, arterial thrombosis, location of the thrombus, lung infiltrate, and mortality were summarized as frequency and percentage. The variables were compared in terms of the ICU and non-ICU groups, using a chi-square/fisher exact test. Data normality was checked with the Shapiro-Wilks test and graphically displayed using a Q-Q plot. Age, cumulative co-morbidities, length of stay, and DVT duration were compared using a t-test. The rate of VTE, bleeding, arterial and composite events were summarized as proportion with the corresponding $95 \%$ confidence intervals $(\mathrm{Cl})$. The risk factors of developing VTE (DVT/PE/ other venous thromboembolism) were identified using logistic regression. The independent variables age, gender improve risk score, weight, baseline D-dimer, baseline platelet, length of hospital stay was selected, based on clinical judgment and univariate analysis. Results are reported as an odds ratio and the corresponding $95 \% \mathrm{Cl}$ and p-values.

The overall survival was compared between patients who had a composite event vs. no composite event, using the Kaplan-Meier with log rank test. A P value of less than 0.05 was considered significant. Statistical analyses were done using SAS version 9.4 (SAS Institute, Cary, NC, USA).

\section{Results}

In total, 651 patients, diagnosed with COVID-19, were enrolled in the study. Only 15 patients were excluded due to admission for less than 24 hours $(n=13)$ and being transferred from another hospital $(n=2)$, with the final sample of 636 patients (Figure 1).

The demographic and baseline characteristics of the sample by the severity group (ICU vs non-ICU) are displayed in Table 1 . The mean age was $49 \pm 16$ years and the majority $(71 \%)$ were male. The mean BMI was $28 \pm 6 \mathrm{~kg} / \mathrm{m}^{2}$. A small proportion $(16.6 \%, \mathrm{n}=106)$ required ICU admission, $1.9 \%(\mathrm{n}=12)$ were diagnosed with cancer and $0.94 \%(n=6)$ had a history of PE or DVT. The median length of hospitalization in the non-ICU group was 7 days compared to the ICU group (19 days). Compared to the non-ICU group, the ICU group consisted of more males, were older and had more comorbidities. At the end of data collection (July 15, 2020), 7.7\% ( $n=49)$ participants died, and the rest were discharged. In terms of pharmacological thromboprophylaxis, the majority $(90 \%, n=573)$, and more than $99 \%$ of the ICU group received pharmacological prophylaxis. The most frequently prescribed regimen $(59.28 \%)$ was enoxaparin $40 \mathrm{mg}$ once daily. Full dose anticoagulation was prescribed for $6.14 \%$ of the sample, due to of a preexisting indication or empirically as part of COVID-19 management (Table 2).

\section{Thrombotic events}




\section{VTE}

Twelve patients were diagnosed with VTE 1.89\% (95\% Cl, 1.18-3). The rate in the non-ICU group was $0.19 \%(95 \% \mathrm{Cl}, 0.04-0.84)$ compared to $10.38 \%(95 \% \mathrm{Cl}, 6.45-16.27)$ in the ICU group. The VTE rate was 21.21 events $(95 \% \mathrm{Cl}, 11.75-38.31)$ per 10000 person-days, compared to the ICU group, 83.14 events (95\% Cl, 46.04-150.13) per 10000 person-days. The cumulative incidence of VTE at 7, 14, and 21 days was $0.47 \%(95 \% \mathrm{Cl}, 0.16-1.37), 0.94 \%(95 \% \mathrm{Cl}, 0.43-2.04)$ and $1.26 \%(95 \% \mathrm{Cl}, 0.63-2.46)$ respectively . The cumulative incidence of VTE in the ICU group at 7, 14, and 21 days was $1.89 \%(95 \% \mathrm{Cl}, 0.51-6.61)$, $4.72 \%(95 \% \mathrm{Cl}, 2.03-10.57)$ and $6.6 \%(95 \% \mathrm{Cl}, 3.23-13.00)$. PE with or without DVT were diagnosed in 8 participants, proximal lower extremity DVT in 4, upper extremity DVT in 1 (line related) and 2 portal vein thrombosis. VTE was diagnosed a median of 13 days after admission. The venous thromboembolism, arterial, and bleeding outcomes in ICU and non-ICU patients are displayed in Table 3.

\section{Arterial Events}

Fourteen patients were diagnosed with an arterial event with an overall rate of $2.20 \%(95 \% \mathrm{Cl}, 1.43-3.38)$. The rate in the non-ICU group was $0.94 \%(95 \% \mathrm{Cl}, 0.46-0.1 .93)$ and $8.49 \%(95 \% \mathrm{Cl}, 5.01-14.04)$ in the ICU group. The arterial event rate was 71.71 events $(95 \% \mathrm{Cl}, 37.31-137.82)$ per 10000 person-days. The arterial events rate was 218.34 events $(95 \% \mathrm{Cl}, 104.09-457.99)$ per 10000 person-days in the ICU group, and $21.40(95 \% \mathrm{Cl}, 5.35-85.58)$ in the non-ICU group. The cumulative incidence of arterial events at 7, 14, and 21 days was $1.57 \%(95 \% \mathrm{Cl}, 0.85-2.86), 2.04 \%(95 \% \mathrm{Cl}, 1.19-3.46)$ and $2.04 \%(95 \% \mathrm{Cl}, 1.19-3.46)$ respectively. The cumulative incidence of arterial events in the ICU group at 7, 14, and 21 days was 5.66\% $(95 \% \mathrm{Cl}, 2.61$ - 11.8), 7.55\% (95\% Cl, 3.87 - 14.19) and 7.55\% (95\% Cl, 3.87 - 14.19). Ten patients developed CVA and 4 patients developed MI.

\section{Composite Events}

The overall composite events rate was $2.99 \%(95 \% \mathrm{Cl}, 2.06-4.31)$. The composite events rate in the nonICU group was $0.94 \%(95 \% \mathrm{Cl}, 0.46-0.1 .93)$ and $13.21 \%(95 \% \mathrm{Cl}, 8.7-19.54)$ in the ICU group. The composite events rate was 25.37 events $(95 \% \mathrm{Cl}, 15.02-42.84)$ per 10000 person-days. The composite events rate was 85.75 events ( $95 \% \mathrm{Cl}, 48.70-151.01)$ per 10000 person-days in the ICU group, and 4.85 $(95 \% \mathrm{Cl}, 1.21-19.41)$ in the non-ICU group (Table 5). The cumulative incidence of composite events on day 7 was 1.42 (95\% Cl, 0.74-2.67), day 141.89 (95\% Cl, 1.08-3.27), and day 21, 2.21 (95\% Cl, 1.313.67).

\section{Bleeding}

Eleven patients developed bleeding with an overall rate of $1.73 \%(95 \% \mathrm{Cl}, 1.06-2.81)$. Five were major bleeding and 6 non-major events. The bleeding rate in the non-ICU group was $0.19 \%(95 \% \mathrm{Cl}, 0.04-0.84)$, and $9.43 \%(95 \% \mathrm{Cl}, 5.72-15.16)$ in the ICU group. The bleeding rate was 22.62 events $(95 \% \mathrm{Cl}, 12.17-$ 42.05) per 10000 person-days and 81.97 events $(95 \% \mathrm{Cl}, 42.65-157.55)$ per 10000 person-days in the ICU group (Table 5). The cumulative incidence of bleeding at 7, 14, and 21 days was $0.16 \%(95 \% \mathrm{Cl}, 0.02$ - 
0.88), $0.94 \%(95 \% \mathrm{Cl}, 0.43-2.04)$ and $1.26 \%(95 \% \mathrm{Cl}, 0.63-2.46)$ respectively. The cumulative incidence of bleeding in the ICU group at 7, 14, and 21 days was $0.94 \%$ (95\% Cl, $0.16-5.15), 4.72 \%(95 \% \mathrm{Cl}, 2.03$ $10.57)$ and $6.6 \%(95 \% \mathrm{Cl}, 3.23-13.00)$.

\section{Risk Factors of developing VTE/Composite Events}

Of the selected risk factors, the only risk factor that predicted VTE and the composite outcome, was the baseline D-dimer. The baseline D-dimer was a significant risk factor for developing VTE (OR 1.31, 95\% Cl, 1.084-1.573, $p=0.005$ ) and composite events (OR 1.32, 95\% Cl, 1.126-1.555, p=0.0007).

\section{Mortality}

In total, 49 participants died with an overall mortality rate of $7.7 \%$. The rate of mortality in the ICU group was $35.85 \%$, compared to $2.08 \%$ in the non-ICU group. The mortality rate was 23.37 deaths $(95 \% \mathrm{Cl}$, 17.66-30.92) per 10000 person-days. The mortality rate was 68.10 deaths (95\% Cl, 49.55-93.59) per 10000 person-days in the ICU group and 7.15 deaths $(95 \% \mathrm{Cl}, 3.96-12.91)$ in the non-ICU group. The participants were more likely to die if they were admitted to ICU (HR 5.0,95\% Cl, 2.31-10.83, $p=<0.0001)$, older than 45 years (HR 5.40,95\% Cl, 1.60-18.21, p=0.006), had a co-morbidity (HR 1.67, 95\% Cl, 0.833.36, $p=0.035$ ), or a composite event (HR 2.30, 95\% Cl, 1.05-5.0, p=0.035) (Table 4). The participants were 3.5 times more likely to die with the composite events (HR3.5, 95\% Cl, 1.75-7.24, $p=0.0005)$.

\section{Discussion}

In this multicentre study, we reported the thrombotic and bleeding complications of 636 COVID-19 patients. The rate of VTE was $1.89 \%(95 \% \mathrm{Cl}, 1.18-3), 0.19 \%(95 \% \mathrm{Cl}, 0.04-0.84)$ and $10.38 \%(95 \mathrm{Cl}$, 6.45-16.27) in all patients, and the non-ICU and ICU groups respectively. The rate of arterial events was $2.20 \%(95 \% \mathrm{Cl}, 1.43-3.38), 0.94 \%$ (95\% Cl, 0.46-1.93) and 8.49\% (95\% Cl, 5.01-14.04) in all patients, non-ICU and ICU groups, respectively. The rate of the composite outcome was $2.99 \%(95 \% \mathrm{Cl}, 2.06-4.31)$, $0.94 \%(95 \% \mathrm{Cl}, 0.46-1.93)$ and $13.21 \%(95 \% \mathrm{Cl}, 8.7-19.54)$ in all the patients, non-ICU and ICU groups respectively. Using logistic regression, the baseline D-dimer was a significant risk factor of developing VTE OR $1.31(95 \% \mathrm{Cl}, 1.08-1.57, \mathrm{p}=0.005)$ and the composite events OR $1.32(95 \% \mathrm{Cl}, 1.12-1.55, \mathrm{p}=$ 0.0007). The rate of VTE in the current study was low compared to some literature ${ }^{10-14}$ but consistent with other studies ${ }^{15-17}$. In a multicentre study in the Netherlands $(n=184){ }^{11}$ with all patients in the ICU and all received standardized doses of nadroparin with a dose escalation at some point during admission to 5700 IU BID in selected patients, the cumulative composite outcome of venous and arterial events was $49 \%$ when adjusting for a competing risk of death (65 PE, 3 other venous and 7 arterial events). Of the PE group, 19 of 65 were subsegmental. Another retrospective study ${ }^{12}$ included 198 patients (74 patients in ICU). All patients in ICU were given thromboprophylaxis at standard or double doses, and $20 \%$ and $49 \%$ were diagnosed with VTE in all the patients compared to the ICU patients, respectively. After adjusting for a competing risk of death, the cumulative incidence of VTE was $42 \%$ in the whole sample, $59 \%$ in ICU group and $9.2 \%$ in patients in a ward on day 21 . Screening for VTE was done in some patients at regular 
intervals. In a prospective study in France ${ }^{13,} 150$ ICU patients with ARDS were compared to patients admitted for non-COVID-19 ARDS. The primary outcome was deep vein thrombosis, pulmonary embolism, myocardial infarction, mesenteric ischemia, lower limb ischemia, or a cerebral ischemic attack. Using propensity score matching, the COVID-19 ARDS patients had higher rates of thrombotic events $(11.7 \%$ versus $2.1 \%$ ). In another multicentre retrospective study with 400 hospital-admitted COVID-19 patients, 144 were critically ill ${ }^{15}$. The VTE (confirmed or presumed) rate was $6 \%, 3.91 \%$ and $10.4 \%$ in all patients, non-critically ill and critically ill respectively. At the last ISTH meeting, a multicentre study was presented which investigated the incidence of VTE and major bleeding in 3239 critically ill adults with COVID-19. The 14-day incidence of VTE was $6.3 \%$. It should be noted that $11.9 \%$ of the patients received therapeutic anticoagulation, though the reason was not mentioned ${ }^{17}$. In terms of arterial complications, the current study had a high rate of arterial events, $8.49 \%(95 \% \mathrm{Cl}, 5.01-14.04)$ in the ICU group. In the previously mentioned study ${ }^{15}$, the rate of arterial thrombosis was $5.6 \%(95 \% \mathrm{Cl}, 2.4-10.7 \%)$ in critically ill patients, which is lower than the rate in our study. Interestingly, most of the events in the current study were CVA, occurring in 4 patients in the non-ICU group and in 6 of the ICU group.

Regarding the bleeding complication, the overall bleeding rate of $1.73 \%(95 \% \mathrm{Cl}, 1.06-2.81)$ is similar to other COVID-19 studies ${ }^{13,17}$ but the rate of bleeding in the ICU group in the current study $(9.43 \%, 95 \% \mathrm{Cl}$, $5.7-15.1)$ is slightly higher than the rate of bleeding $(7.6 \%(95 \% \mathrm{Cl}, 3.9-13.3 \%)$ reported in the previous study ${ }^{15}$. Most of the bleeding events were non-major and if we calculated the rate of major bleeding only, it was $3.7 \%$ in the ICU group which is similar to non-COVID-19 patients ${ }^{19,20}$.

The conflicting results of thrombotic complications in COVID-19 patients in these studies, including our study, could be partially explained by the different threshold for admission to hospital or ICU. In our study, the mean age was lower than other studies. The definition of a thrombotic outcome was not the same in the studies, the follow-up period was variable, with different prophylaxis regimes (in the current study more than $90 \%$ received pharmacological prophylaxis and almost all patients in ICU received prophylaxis), and screening for a thrombotic complication, such as a Doppler US, could explain the differences in the studies. Also, the diagnosis of $\mathrm{Ml}$ in our study was based the physician's judgment, based on a combination of clinical and laboratory results and not confirmed by a coronary angiogram. This may partially explain the high rate of arterial events although most of the arterial events were CVA. Table 6 displays the selected studies.

The difference in thrombotic outcomes in COVID-19 resulted in controversies in guidelines of major societies for the prevention of this complication. The ISTH Guidance ${ }^{21}$ suggested thromboprophylaxis with a prophylactic-dose UFH or LMWH with the possibility to escalate to an Intermediate-dose for high risk and a $50 \%$ increase in the dose for obese patients. The CHEST guidelines ${ }^{22}$ suggested the current standard dose anticoagulant thromboprophylaxis over intensifying the dose to intermediate or full treatment dosing. In addition to an accurate estimate of the risk of thrombosis, there are areas requiring further investigation. There is limited evidence regarding the risk of bleeding in these patients. From the available evidence, the rate of major bleeding is variable and ranges from $<1 \%$ in ward patients to $7.6 \%$ in 
ICU patients ${ }^{15,17}$ (8.49\% in our study). This needs to be confirmed in well-designed prospective studies. A second question is the case fatality rate of thrombotic and bleeding events, it is urgent to establish whether it is same as for non-COVID-19 patients. This will support making a decision based on the risks and benefits of prophylaxis. There is also no definitive optimal method for assessing the risk for VTE. Would a risk assessment such as Caprini, IMPROVE, the Padua model, and others be able to risk stratify these patients? In terms of the diagnosis of VTE in COVID-19 patients, would a pre-test probability using prediction models such as the Wells or Geneva and biomarkers such as the D-dimer be able to exclude VTE in these patients without the need for imaging studies as it is known that most of the COVID-19 patients have a high D-dimer level. Another unresolved issue is to determine the optimal dose of prophylactic anticoagulation, the duration of the anticoagulation prophylaxis, should it be continued as outpatients or not. In a large study ${ }^{22}$ of 1,877 patients, the rate of post-discharge VTE was 4.8 per 1000 discharges over 42 days follow-up, which is similar to a discharge associated VTE in non-COVID-19 medical admissions, with the odds ratio for post-discharge HA-VTE associated with COVID-19 compared to non-COVID-19 of $1.6(95 \% \mathrm{Cl}, 0.77-3.1)$. As of the 15th of August 2020, 46 randomized clinical trials was listed in clinicaltrials.gov using varying intensity of anticoagulation and investigating different outcomes, for example the thrombosis rate, mortality and other complications, such as ICU admission. The evidence generated through these studies is expected to strengthen the evidence related to this special population.

The strengths of the current study, firstly, is the multicenter setting of the study, conducted in four different hospitals, two community based and academic teaching hospitals, representing most of the population and increasing the probability of generalizability. Secondly, the relatively large sample size. Thirdly, at the end of data collection, all the participants were discharged or died, compared to other studies where some patients were still in hospital, which could have resulted in an underestimation of the outcome.

This study is limited by its retrospective nature. Although we included not only confirmed but also suspected VTE, some cases of VTE may have been missed as there was no uniform protocol to exclude VTE in any of the four centres. In addition, the diagnosis of MI was based on physician judgment, taking in consideration a combination of clinical, laboratory and other evidence, and was not confirmed by a coronary angiogram. This may explain the high rate of arterial events. Another limitation is the small number of ICU admitted patients compared to non-ICU patients, which is probably secondary to a low threshold for admission of COVID-19 patients in ICUs.

\section{Conclusion}

Of 636 adults with COVID-19, the rate of VTE was similar to the rate of hospitalized patients with a similar degree of critical illness. In contrast to the risk of VTE, we found a high rate of arterial and venous bleeding complications in patients admitted to ICU. An elevated D-dimer at baseline could predict a thrombotic complication in the COVID-19 patients, which may assist in the identification of these patients. Given the high rate of bleeding, the current study suggests that the intensification of 
anticoagulation in COVID-19 patients beyond the standard of care, should be pursued with caution and is best evaluated in a randomised controlled study.

\section{Declarations}

\section{Authorship contribution :}

A Al Raizah wrote the first draft of the manuscript and contributed to study design, creation of tables and figures, critical revision of the manuscript, and final approval; M Al morgen contributed to study design , creation of tables and figures, critical revision of the manuscript, and final approval; N Ashraf contributed to study design , data analysis, creation of tables and figures, critical revision of the manuscript, and final approval; all other authors contributed to data collection ,critical revision of the manuscript, and final approval.

\section{Conflicts of interest:}

The authors have no conflicts of interest to declare.

\section{References}

1. Society of Hospital Medicine, Maynard GA, Stein JM. Preventing hospital-acquired venous thromboembolism: a guide for effective quality improvement. Agency for Healthcare Research and Quality, US Department of Health and Human Services; 2008.

2. Heit JA. Venous thromboembolism epidemiology: implications for prevention and management. InSeminars in thrombosis and hemostasis 2002 (Vol. 28, No. s2, pp. 003-014). Copyright@ 2002 by Thieme Medical Publishers, Inc., 333 Seventh Avenue, New York, NY 10001, USA. Tel.:+ 1 (212) 5844662.

3. Barbar S, Prandoni P. Scoring systems for estimating risk of venous thromboembolism in hospitalized medical patients. InSeminars in thrombosis and hemostasis $2017 \mathrm{Jul}$ (Vol. 43, No. 05, pp. 460-468). Thieme Medical Publishers.

4. Hull RD, Merali T, Mills A, Stevenson AL, Liang J. Venous thromboembolism in elderly high-risk medical patients: time course of events and influence of risk factors. Clinical and Applied Thrombosis/Hemostasis. 2013 Jul;19(4):357-62.

5. Zeidan AM, Streiff MB, Lau BD, Ahmed SR, Kraus PS, Hobson DB, Carolan H, Lambrianidi C, Horn PB, Shermock KM, Tinoco G. Impact of a venous thromboembolism prophylaxis "smart order set": improved compliance, fewer events. American journal of hematology. 2013 Jul;88(7):545-9.

6. Mitchell JD, Collen JF, Petteys S, Holley AB. A simple reminder system improves venous thromboembolism prophylaxis rates and reduces thrombotic events for hospitalized patients 1 . Journal of Thrombosis and Haemostasis. 2012 Feb;10(2):236-43. 
7. Lau BD, Haut ER. Practices to prevent venous thromboembolism: a brief review. BMJ quality \& safety. 2014 Mar 1;23(3):187-95.

8. Guan WJ, Ni ZY, Hu Y, Liang WH, Ou CQ, He JX, Liu L, Shan H, Lei CL, Hui DS, Du B. Clinical characteristics of coronavirus disease 2019 in China. New England journal of medicine. 2020 Apr 30;382(18):1708-20.

9. Zhou F, Yu T, Du R, Fan G, Liu Y, Liu Z, Xiang J, Wang Y, Song B, Gu X, Guan L. Clinical course and risk factors for mortality of adult inpatients with COVID-19 in Wuhan, China: a retrospective cohort study. The lancet. 2020 Mar 11.

10. Poissy J, Goutay J, Caplan M, Parmentier E, Duburcq T, Lassalle F, Jeanpierre E, Rauch A, Labreuche J, Susen S. Pulmonary embolism in COVID-19 patients: awareness of an increased prevalence. Circulation. 2020 Apr 24.

11. Klok FA, Kruip MJ, Van Der Meer NJ, Arbous MS, Gommers DA, Kant KM, Kaptein FH, van Paassen J, Stals MA, Huisman MV, Endeman $\mathrm{H}$. Confirmation of the high cumulative incidence of thrombotic complications in critically ill ICU patients with COVID-19: an updated analysis. Thrombosis research. 2020 Apr 30.

12. Middeldorp S, Coppens M, van Haaps TF, Foppen M, Vlaar AP, Müller MC, Bouman CC, Beenen LF, Kootte RS, Heijmans J, Smits LP. Incidence of venous thromboembolism in hospitalized patients with COVID-19. Journal of Thrombosis and Haemostasis. 2020 May 5.

13. Helms J, Tacquard C, Severac F, Leonard-Lorant I, Ohana M, Delabranche X, Merdji H, Clere-Jehl R, Schenck M, Gandet FF, Fafi-Kremer S. High risk of thrombosis in patients with severe SARS-CoV-2 infection: a multicenter prospective cohort study. Intensive care medicine. 2020 May 4:1-0.

14. Lodigiani C, lapichino G, Carenzo L, Cecconi M, Ferrazzi P, Sebastian T, Kucher N, Studt JD, Sacco C, Alexia B, Sandri MT. Venous and arterial thromboembolic complications in COVID-19 patients admitted to an academic hospital in Milan, Italy. Thrombosis research. 2020 Apr 23.

15. Al-Samkari H, Karp Leaf RS, Dzik WH, Carlson JC, Fogerty AE, Waheed A, Goodarzi K, Bendapudi P, Bornikova L, Gupta S, Leaf D. COVID and Coagulation: Bleeding and Thrombotic Manifestations of SARS-CoV2 Infection. Blood. 2020 Jun 3.

16. Mei F, Fan J, Yuan J, Liang Z, Wang K, Sun J, Guan W, Huang M, Li Y, Zhang WW. Comparison of Venous Thromboembolism Risks Between COVID-19 Pneumonia and Community-Acquired Pneumonia Patients. Arteriosclerosis, Thrombosis, and Vascular Biology. 2020 Jul 6:ATVBAHA-120.

17. Al-Samkari H, Gupta S, Karp Leaf R, Wang W, Rosovsky R, Bauer K, Leaf D, STOP-COVID Investigators. Thrombosis, Bleeding, and the Effect of Anticoagulation on Survival in Critically III Patients with COVID-19 in the United States [abstract]. Res Pract Thromb Haemost. 2020; 4 (Suppl 1). https://abstracts.isth.org/abstract/thrombosis-bleeding-and-the-effect-of-anticoagulation-onsurvival-in-critically-ill-patients-with-covid-19-in-the-united-states/. Accessed August 19, 2020.

18. Schulman S, Kearon C, Subcommittee on Control of Anticoagulation of the Scientific and Standardization Committee of the International Society on Thrombosis and Haemostasis. Definition 
of major bleeding in clinical investigations of antihemostatic medicinal products in non-surgical patients. Journal of Thrombosis and Haemostasis. 2005 Apr;3(4):692-4.

19. PROTECT Investigators for the Canadian Critical Care Trials Group and the Australian and New Zealand Intensive Care Society Clinical Trials Group. Dalteparin versus unfractionated heparin in critically ill patients. New England Journal of Medicine. 2011 Apr 7;364(14):1305-14.

20. Lauzier F, Arnold DM, Rabbat C, Heels-Ansdell D, Zarychanski R, Dodek P, Ashley BJ, Albert M, Khwaja $\mathrm{K}$, Ostermann M, Skrobik Y. Risk factors and impact of major bleeding in critically ill patients receiving heparin thromboprophylaxis. Intensive care medicine. 2013 Dec 1;39(12):2135-43.

21. Spyropoulos AC, Levy JH, Ageno W, Connors JM, Hunt BJ, Iba T, Levi M, Samama CM, Thachil J, Giannis D, Douketis JD. Scientific and Standardization Committee Communication: Clinical Guidance on the Diagnosis, Prevention and Treatment of Venous Thromboembolism in Hospitalized Patients with COVID-19. Journal of Thrombosis and Haemostasis. 2020 May 27.

22. Moores LK, Tritschler T, Brosnahan S, Carrier M, Collen JF, Doerschug K, Holley AB, Jimenez D, Le Gal G, Rali P, Wells P. Prevention, Diagnosis, and Treatment of VTE in Patients With Coronavirus Disease 2019: CHEST Guideline and Expert Panel Report. Chest. 2020 Jun 2.

23. Roberts LN, Whyte MB, Georgiou L, Giron G, Czuprynska J, Rea C, Vadher B, Patel R, Gee E, Arya R. Post-discharge venous thromboembolism following hospital admission with COVID-19. Blood. 2020 Aug 3.

\section{Tables}


Table 1

Demographic and Baseline Characteristics of Sample

\begin{tabular}{|c|c|c|c|c|}
\hline & $\begin{array}{l}\text { Overall } \\
n=636\end{array}$ & $\begin{array}{l}\text { Non-ICU } \\
n=530\end{array}$ & $\begin{array}{l}\text { ICU } \\
n=106\end{array}$ & p-value \\
\hline Age $($ mean $\pm S D)$ & $\begin{array}{l}49.47 \pm \\
16.39\end{array}$ & $\begin{array}{l}47.5 \pm \\
16.12\end{array}$ & $\begin{array}{l}59.32 \pm \\
14.08\end{array}$ & $<.0001^{\wedge}$ \\
\hline Male $n(\%)$ & $456(71.7)$ & $371(70)$ & $85(80.2)$ & $0.033^{*}$ \\
\hline Female $n(\%)$ & $180(28.3)$ & $159(30)$ & 21(19.8) & \\
\hline Weight (mean \pm SD) & $\begin{array}{l}78.16 \pm \\
16.23\end{array}$ & $77.2 \pm 15.1$ & $\begin{array}{l}82.87 \pm \\
20.30\end{array}$ & $0.0079^{\wedge}$ \\
\hline $\begin{array}{l}\text { BMI (mean } \pm \text { SD) } \\
\text { Nationality } n(\%)\end{array}$ & $28.45 \pm 6.04$ & $\begin{array}{l}28.14 \pm \\
5.56\end{array}$ & $17.31 \pm 7.80$ & $0.0753^{\wedge \wedge}$ \\
\hline Saudi & $350(55)$ & $296(55.8)$ & $54(51)$ & $0.354^{\star}$ \\
\hline Non-Saudi & $286(45)$ & $234(44.1)$ & $52(49)$ & \\
\hline $\begin{array}{l}{ }^{\wedge} \text { Cumulative co-morbidities (median, } \\
\text { range) }\end{array}$ & $0(0-8)$ & $0(0-5)$ & $1(0-5)$ & $<.0001^{\wedge}$ \\
\hline Active Cancer n (\%) & $12(1.9)$ & $9(1.7)$ & $3(2.83)$ & $0.432^{\star \star}$ \\
\hline History of Thrombophilia n (\%) & $3(0.47)$ & $1(0.19)$ & $2(1.89)$ & $0.073^{\star \star}$ \\
\hline History of DVT/ PE n (\%) & $6(0.94)$ & $5(0.95)$ & $1(0.94)$ & $1.00 * \star$ \\
\hline \multicolumn{5}{|c|}{ 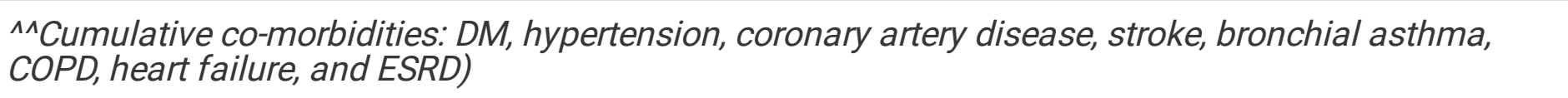 } \\
\hline \multicolumn{5}{|l|}{${ }^{*}$ chi-square test } \\
\hline \multicolumn{5}{|l|}{ **Fisher exact test } \\
\hline ^Student's t-test & & & & \\
\hline
\end{tabular}


Table 2

Treatment received by the sample

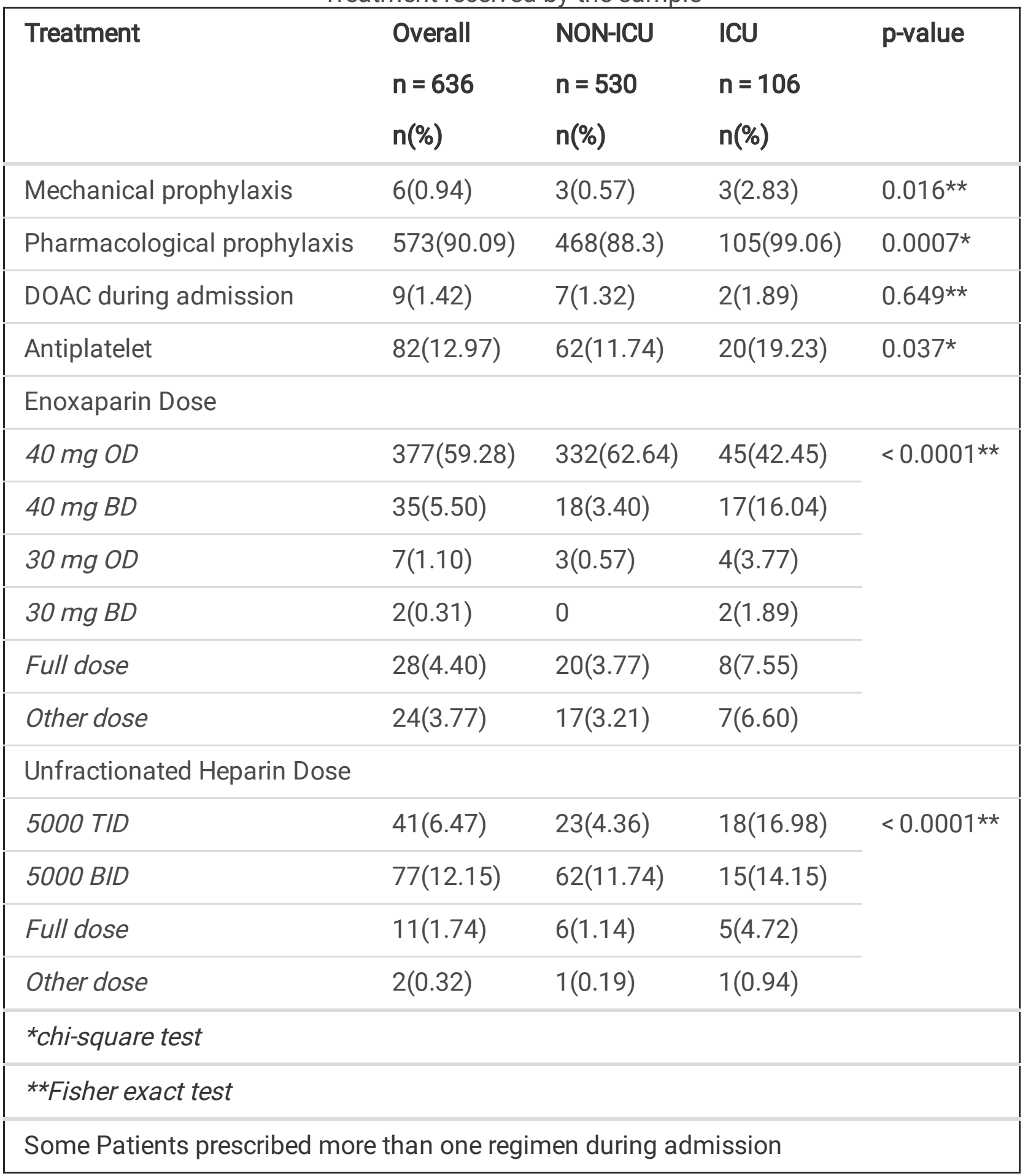


Table 3

Outcome Data

\begin{tabular}{|llll|}
\hline Variables & Overall & Non-ICU & ICU \\
\hline VTE \% (95\% Cl) & $1.89(1.18-3)$ & $0.19(0.04-0.84)$ & $10.38(6.45-16.27)$ \\
\hline PE n (\%) & $8(1.26)$ & 0 & $8(7.55)$ \\
\hline DVT n (\%) & $5(0.79)$ & 0 & $5(4.72)$ \\
\hline Proximal upper $\mathrm{n} \%)$ & $1(0.16)$ & 0 & $1(0.94)$ \\
\hline Proximal lowern (\%) & $4(0.63)$ & 0 & $4(3.77)$ \\
\hline Other venous thrombosis n & $2(0.31)$ & $1(0.19)$ & $1(0.94)$ \\
\hline \%) & & & \\
\hline Arterial thrombosis rate & $2.20(1.43-3.38)$ & $0.94(0.46-1.93)$ & $8.49(5.01-14.04)$ \\
\hline$\%(95 \% C I)$ & & & $6(5.66)$ \\
\hline CVA $\mathrm{n}(\%)$ & $10(1.57)$ & $4(0.75)$ & $3(2.83)$ \\
\hline MIn (\%) & $4(0.63)$ & $1(0.19)$ & $9.43(5.7-15.1)$ \\
\hline Bleeding\% (95\%CI) & $1.73(1.06-2.8)$ & $0.19(0.04-0.84)$ & $4(3.7)$ \\
\hline Major bleeding $\mathrm{n}(\%)$ & $5(0.78)$ & $1(0.19)$ & $6(5.66)$ \\
\hline Other bleeding $\mathrm{n}(\%)$ & $6(0.94)$ & 0 & $13.21(8.7-19.54)$ \\
\hline Composite events\% (95\%CI) & $2.99(2.06-4.31)$ & $0.94(0.46-1.93)$ & \\
\hline
\end{tabular}

Table 4

Risk Factors for Mortality in the sample

\begin{tabular}{|llll|}
\hline & Hazard Ratio & $95 \% \mathrm{Cl}$ & P-value \\
\hline Age ( $\geq 45$ years vs. less than 45) & 5.40 & $1.60-18.21$ & 0.006 \\
\hline BMI ( $\geq 30$ vs. less than 30) & 1.12 & $0.60-2.08$ & 0.707 \\
\hline Admitted in (ICU vs. non-ICU) & 5.01 & $2.31-10.83$ & $<0.0001$ \\
\hline Cumulative co-morbidity ( $\geq$ one vs. 0) & 1.67 & $0.83-3.35$ & 0.035 \\
\hline Lung infiltrate (yes vs no) & 1.26 & $0.60-2.64$ & 0.531 \\
\hline Composite event (yes vs no) & 2.30 & $1.05-5.01$ & 0.035 \\
\hline *Composite events (DVT/PE/ other venous thromboembolism/arterial events) \\
\hline *The reference groups are italicized & & & \\
\hline
\end{tabular}


Table 5

Selected studies

\begin{tabular}{|c|c|c|c|c|c|}
\hline Study & Pt & Thrombosis & bleeding & Prophylaxis & notes \\
\hline $\begin{array}{l}\text { Al-Samkari } \\
\text { et al } 17 \\
\\
\end{array}$ & $\begin{array}{l}\text { i } 3239 \\
\text { all ICU } \\
\text { Median age } \\
61 \\
\text { Follow up } 14 \\
\text { days }\end{array}$ & VTE $6.3 \%$ & $2.8 \%$ & & $\begin{array}{l}11.9 \% \text { received } \\
\text { full dose } \\
\text { anticoagulation }\end{array}$ \\
\hline Mei et al ${ }^{16}$ & $\begin{array}{l}626 \text { with } \\
\text { pneumonia } \\
\text { Median age } \\
55 \\
16.1 \% \\
\text { ventilator } \\
\text { support } \\
6.3 \text { mortality }\end{array}$ & $\begin{array}{l}\text { VTE } 2 \% \\
\text { ICU } 6.7 \% \\
12.5 \% \text { in patients } \\
\text { with Padua more } \\
\text { than } 4 \\
1 \text { with arterial } \\
\text { ischemia (ventilator } \\
\text { support }\end{array}$ & & $\begin{array}{l}\text { All patients received VTE } \\
\text { prophylaxis following standard } \\
\text { protocols or mechanical } \\
\text { intermittent pneumatic } \\
\text { compression device }\end{array}$ & $\begin{array}{l}\text { Outcome } \\
\text { definition not } \\
\text { mentioned } \\
\text { No mention } \\
\text { about } \mathrm{f} / \mathrm{u}\end{array}$ \\
\hline $\begin{array}{l}\text { Klok et al } \\
11\end{array}$ & $\begin{array}{l}184 \text { ICU } \\
\text { Mean age } 64 \\
\text { Median } \\
\text { follow up } \\
14 \text { days (IQR } \\
6-19) \\
22 \% \\
\text { mortality }\end{array}$ & $\begin{array}{l}\text { The cumulative } \\
\text { incidence of the } \\
\text { composite outcome, } \\
\text { adjusted for } \\
\text { competing risk of } \\
\text { death, was } 49 \% \\
(95 \% \text { confidence } \\
\text { interval [Cl] } 41- \\
57 \%) \text {. }\end{array}$ & & $\begin{array}{l}\text { All patients received } \\
\text { pharmacological } \\
\text { thromboprophylaxis according to } \\
\text { local hospital protocols }\end{array}$ & $\begin{array}{l}29 \% \text { of PE were } \\
\text { subsegmental } \\
65 \text { out of } 184 \\
\text { patients were } \\
\text { still admitted }\end{array}$ \\
\hline $\begin{array}{l}\text { Middeldorp } \\
\text { et al }{ }^{12} \\
\end{array}$ & $\begin{array}{l}\text { p } 198 \text { (74 ICU) } \\
\text { Median age } \\
61 \\
\text { median } \\
\text { follow-up of } \\
7 \text { days (IQR, } \\
3-13) \\
\text { Mortality } \\
19 \%\end{array}$ & $\begin{array}{l}\text { VTE } \\
20 \% \text { total } \\
47 \% ; \text { ICU } \\
3.3 \% \text {; ward }\end{array}$ & 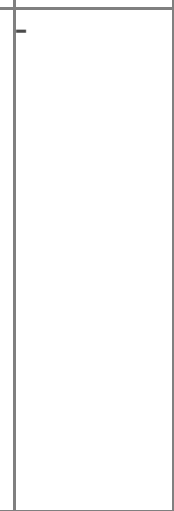 & $\begin{array}{l}\text { Thrombosis prophylaxis was part } \\
\text { of standard of care in all COVID- } \\
19 \text { patients. Ward patients } \\
\text { received thrombosis prophylaxis } \\
\text { with nadroparin } 2850 \text { IU once } \\
\text { daily or } 5700 \text { IU for patients with a } \\
\text { body weight of more than } 100 \mathrm{~kg} \text {. } \\
\text { Dose escalation for patients in ICU } \\
\text { to } 2850 \text { IU twice daily for patients } \\
\text { with a body weight }<100 \mathrm{~kg} \text { and } \\
5700 \text { IU twice daily for those more } \\
\text { than } 100 \mathrm{~kg} \text {. }\end{array}$ & $\begin{array}{l}\text { screening for } \\
\text { lower extremity } \\
\text { DVT was } \\
\text { performed in } \\
55 \text { patients } \\
(28 \%) \text { during } \\
\text { hospital stay } \\
\end{array}$ \\
\hline $\begin{array}{l}\text { Helms et al } \\
13 \\
\\
\end{array}$ & $\begin{array}{l}1150 \text { ICU } \\
\text { ARDS } \\
\text { median age } \\
63 \\
\text { The median } \\
\text { length of } \\
\text { stay } 9.6 \text { days } \\
\text { mortality rate } \\
\text { was } 8.7 \%\end{array}$ & $\begin{array}{l}18 \% \\
\text { venous and arterial }\end{array}$ & $2.7 \%$ & $\begin{array}{l}\text { LMWH (exact agent not specified) } \\
4000 \text { Units per day or UFH 5- } \\
8 \mathrm{Ug} / \mathrm{kg} \text { in } 70 \% \\
30 \% \text { full dose anticoagulation }\end{array}$ & $\begin{array}{l}67.3 \% \text { were still } \\
\text { intubated at the } \\
\text { time of data } \\
\text { analysis }\end{array}$ \\
\hline $\begin{array}{l}\text { Al-Samkari } \\
\text { et al } 15\end{array}$ & $\begin{array}{l}400(144 \\
\text { ICU) } \\
\text { Age } 60 / 64 \\
\text { ICU }\end{array}$ & $\begin{array}{l}\text { VTE } 6 \% \text { all } \\
3.91 \% \text { non-critically } \\
\text { ill } \\
10.4 \% \text { critically ill } \\
\text { Arterial } 2.8 \text { all } \\
1.2 \text { non critically ill } \\
5.6 \% \text { critically ill }\end{array}$ & $\begin{array}{l}4.8 \% \text { all } \\
, 3.1 \text { non } \\
\text { critically } \\
\text { ill } \\
7.6 \% \\
\text { critically } \\
\text { ill }\end{array}$ & $\begin{array}{l}\text { Standard prophylactic } \\
\text { anticoagulation } 90.2 \% \\
\text { In ICU (86.1\%) } \\
\text { Intermediate or full-dose } \\
\text { anticoagulation, } 6.6 \% \text { (in } \\
\text { icu12.5\%) }\end{array}$ & $\begin{array}{l}\text { They includes } \\
\text { superficial vein } \\
\text { thrombosis as } \\
\text { VTE event ( } 2 / \\
19 \text { patients ) }\end{array}$ \\
\hline
\end{tabular}

Figures 


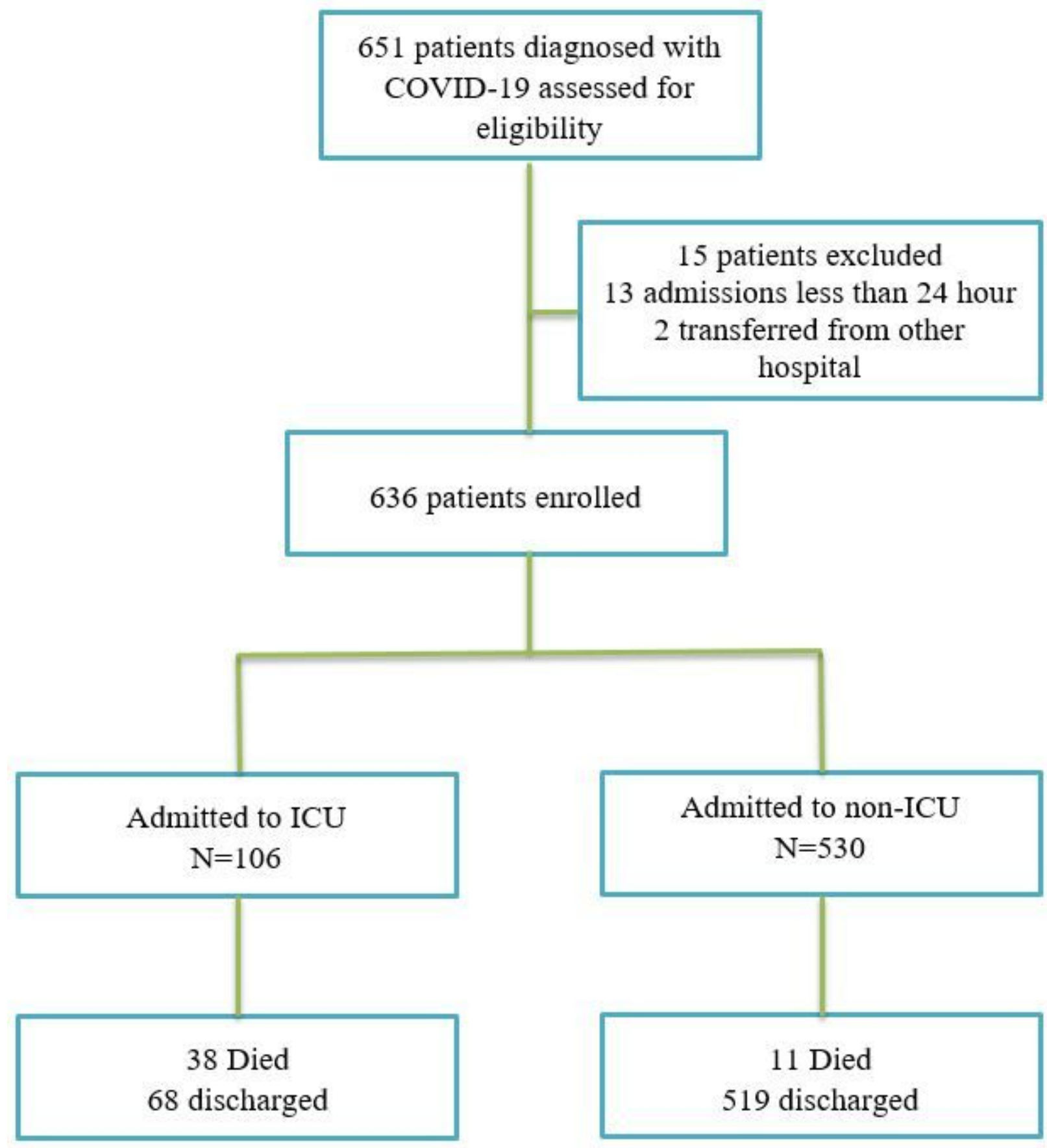

Figure 1

Study Flow Chart 